\title{
26. SYNTHESIS OF OXYGEN AND CARBON ISOTOPIC RESULTS FROM SITE 704: IMPLICATIONS FOR MAJOR CLIMATIC-GEOCHEMICAL TRANSITIONS DURING THE LATE NEOGENE ${ }^{1}$
}

\author{
David A. Hodell, ${ }^{2}$ Daniel W. Müller, ${ }^{2}$ Paul F. Ciesielski, ${ }^{2}$ and Gregory A. Mead ${ }^{2}$
}

\begin{abstract}
Composite oxygen and carbon isotopic records of planktonic and benthic foraminifers and fine-fraction $(<63 \mu \mathrm{m})$ carbonate were used to identify major paleoceanographic events in subantarctic surface and deep waters during the past $10 \mathrm{Ma}$. The late Neogene record of the subantarctic Southern Ocean is marked by progressive intensification of glacial-interglacial cycles, migrations of the Polar Front Zone, and changes in deep-water circulation. The two most important times of rapid paleoceanographic change occurred during the late Miocene (between 6.4 and $4.8 \mathrm{Ma}$ ) and late Pliocene (especially at $\sim 2.5 \mathrm{Ma}$ ).
\end{abstract}

\section{INTRODUCTION}

In this paper we summarize the major results of oxygen and carbon isotopic analyses of planktonic and benthic foraminifers and fine-fraction carbonate from Ocean Drilling Program (ODP) Site 704 during the late Neogene. Our objective is to present all of the isotopic data from individual studies in this volume to provide an overview of the paleoceanographic history of the subantarctic South Atlantic during the past 10 $\mathrm{Ma}$. The composite data from Holes $704 \mathrm{~A}$ and $704 \mathrm{~B}$ represent a long, continuously sampled isotopic record with which to evaluate the paleoclimatic evolution of the high-latitude Southern Ocean.

The hydrographic setting of Site 704 makes its sediment record extremely sensitive to past surface- and deep-water circulation changes in the Southern Ocean. It is located just north of the present axis of the Polar Front Zone (PFZ), which marks a steep gradient in temperature, nutrient content, and productivity of surface waters. For example, over a latitudinal range of only $10^{\circ}$ in the subantarctic, the predicted gradient in the oxygen isotopic composition of calcite in equilibrium with surface water is roughly three times that expected for full glacial-interglacial cycles (Charles and Fairbanks, 1990). Bathymetrically, the site is positioned in upper deep waters $(2532 \mathrm{~m})$ that are a mixture of Circumpolar Deep Water (CPDW) and North Atlantic Deep Water (NADW). Benthic foraminiferal oxygen and carbon isotopes at Site 704 should be highly sensitive to the relative mixing ratios of these two water masses in the past.

\section{METHODS}

The methods and tabulation of data can be found in the individual manuscripts in this volume. The late Miocene-early Pliocene foraminiferal isotopic data are from Müller et al. (this volume), the Pliocene-Pleistocene foraminiferal isotopic data are from Hodell and Ciesielski (this volume), and the finefraction carbonate isotopic data are from Mead et al. (this volume). All planktonic analyses were made on Neogloboquadrina pachyderma (sinistral) and benthic analyses were

${ }^{1}$ Ciesielski, P. F., Kristoffersen, Y., et al., 1991. Proc. ODP, Sci. Results, 114: College Station, TX (Ocean Drilling Program).

${ }^{2}$ Department of Geology, University of Florida, Gainesville, FL 32611 (Müller, present address: Geologisches Institut, Swiss Federal Institute of Technology, ETH-Zentrum, 8092 Zürich, Switzerland). made on mixed species of Cibicides. All isotopic data are expressed relative to PDB and are uncorrected for species departures from equilibrium. The oxygen and carbon isotopic data for the fine-fraction carbonate extend to a depth of $300 \mathrm{~m}$ below seafloor (mbsf) $(\sim 7.9 \mathrm{Ma})$, whereas the foraminiferal isotopic data extend to $380 \mathrm{mbsf}(\sim 10 \mathrm{Ma})$. The sample spacing is not constant and varies substantially in time because of changes in the sedimentation rate (see the individual manuscripts for details of sample spacing).

\section{RESULTS}

\section{Oxygen Isotopes}

Figure 1 shows the planktonic $\delta^{18} \mathrm{O}$ record of Neogloboquadrina pachyderma for the last $10 \mathrm{Ma}$. For comparison, typical glacial $(\mathrm{G})$ and Holocene $(\mathrm{H}) \delta^{18} \mathrm{O}$ values are shown from piston cores recovered nearby Site 704 in the South Atlantic sector of the Southern Ocean (Charles and Fairbanks, 1990). The average amplitude of the glacial-interglacial $\delta^{18} \mathrm{O}$ signal of $N$. pachyderma is $1.3 \%$ between $41^{\circ}$ and $60^{\circ} \mathrm{S}$ (Charles and Fairbanks, 1990).

During the late Miocene $(370-250 \mathrm{mbsf}), \delta^{18} \mathrm{O}$ values averaged $\sim 1.75 \%$ oo. The latest Miocene interval, between $\sim 6.3$ and $4.8 \mathrm{Ma}$ (250-220 mbsf), was marked by anomalously high-amplitude $\delta^{18} \mathrm{O}$ variations in which the total range of the signal was $3 \%$. Planktonic $\delta^{18} \mathrm{O}$ ratios twice exceeded Holocene values from the tops of cores, but the average ratios generally remained significantly less than those of the Holocene (Fig. 1).

Between 4.2 and $3.9 \mathrm{Ma}(210-200 \mathrm{mbsf}), \delta^{18} \mathrm{O}$ values increased by $\sim 0.5 \%$ oo and averaged $2.25 \%$ oo during the early Pliocene. From 3.6 to $2.47 \mathrm{Ma}$, planktonic $\delta^{18} \mathrm{O}$ values oscillated about the Holocene value with an amplitude of less than $1 \%$. This was followed by a pronounced increase in mean planktonic $\delta^{18} \mathrm{O}$ values by $0.5 \%$ across the Gauss/Matuyama boundary at $2.47 \mathrm{Ma}(169 \mathrm{mbsf})$. The amplitude of the signal during the late Pliocene was $\sim 1 \%$, and $\delta^{18} \mathrm{O}$ values did not reach those of the last glacial maximum $(3.5 \%$ oo $)$ until 112 mbsf ( 1.8 Ma). Above $\sim 112 \mathrm{mbsf}$, the amplitude of the $\delta^{18} \mathrm{O}$ signal is comparable and sporadically greater than the difference in $\delta^{18} \mathrm{O}$ values between the last glacial and the Holocene.

The benthic oxygen isotopic record is shown in Figure 2. To compare these results with an oxygen isotopic record over the last climatic cycle, we used estimates of glacialHolocene amplitudes from nearby piston cores (average 


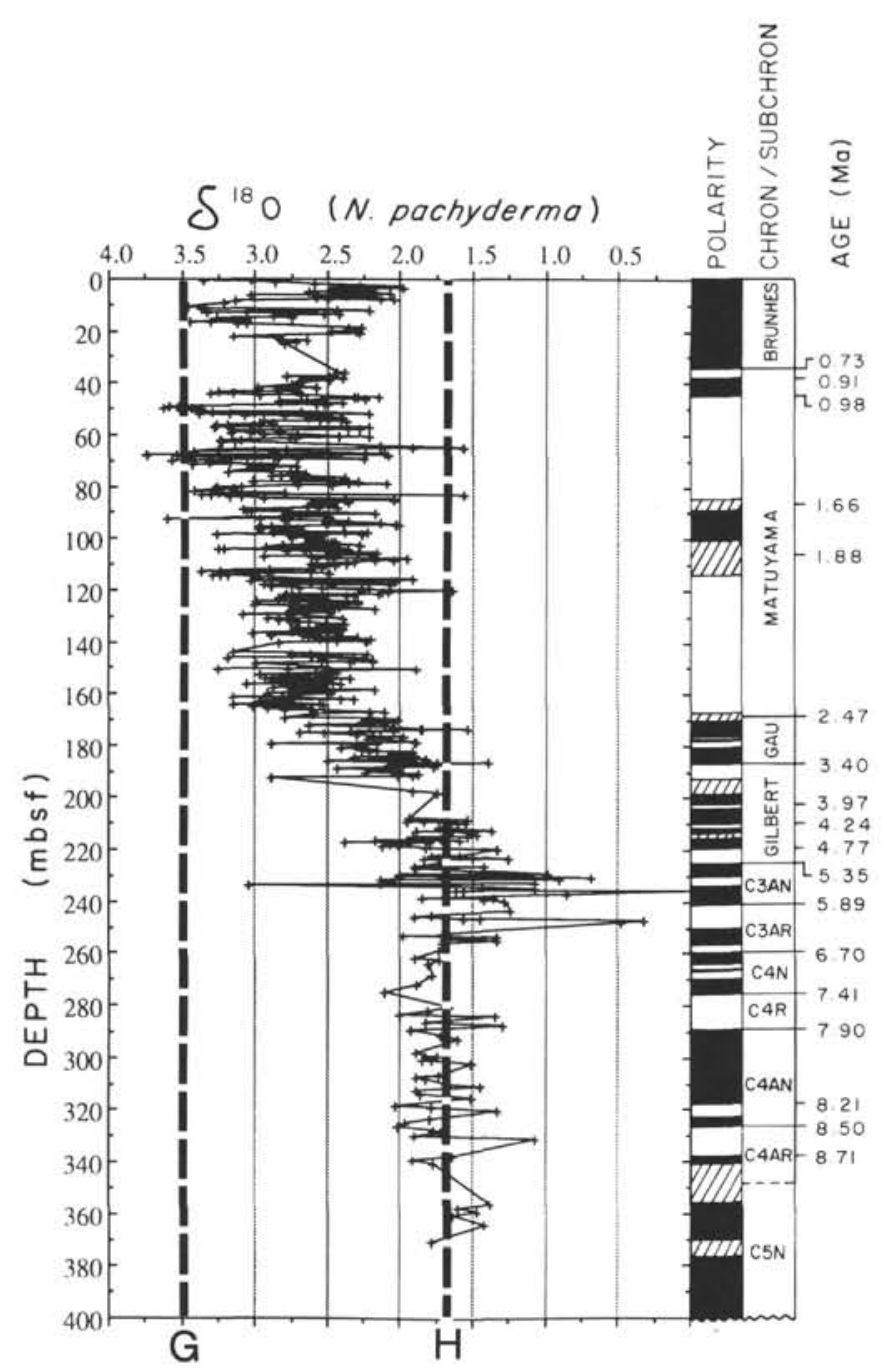

Figure 1. Oxygen isotopic results (per mil relative to PDB) of the planktonic foraminifer Neogloboquadrina pachyderma (sinistral) from Site 704. Late Miocene-early Pliocene data are from Müller et al. (this volume) and Pliocene-Pleistocene data are from Hodell and Ciesielski (this volume). The hatched pattern in the magnetostratigraphy (after Hailwood and Clement, this volume) reflects uncertainty in the placement of some polarity reversal boundaries. Note increases in average $\delta^{18} \mathrm{O}$ values between 210 and $200 \mathrm{mbsf}(4.2-3.9 \mathrm{Ma})$ and across the Gauss/Matuyama boundary ( $2.47 \mathrm{Ma}$ ) at $169 \mathrm{mbsf}$. For comparison, the glacial $(\mathrm{G}) \delta^{18} \mathrm{O}$ value of $N$. pachyderma at this latitude is $\sim 3.5 \%$ and the Holocene $(\mathrm{H})$ value is $\sim 2.2 \%$ (Charles and Fairbanks, 1990).

$1.6 \%-1.7 \%$ oo), which are also consistent with the signal amplitude in the upper $40 \mathrm{~m}$ at Site 704 .

At Site 704 , benthic $\delta^{18} \mathrm{O}$ values averaged $2.25 \%$ oo between 9.7 and $8.7 \mathrm{Ma}$ (380-340 mbsf) and increased to $2.5 \%$ by $8.3 \mathrm{Ma}$ (320 mbsf; Fig. 2). From 6.3 to $5.4 \mathrm{Ma}$ (250-226 mbsf), the benthic oxygen isotopic record was marked by a relatively high-amplitude signal with maximum $\delta^{18} \mathrm{O}$ values reaching $3 \%$. During the late Miocene, average benthic $\delta^{18} \mathrm{O}$ values were less than the estimated Holocene core-top value $(2.5 \%$ oo- $2.6 \%$, but Holocene values were commonly exceeded during Chrons 4 and $\mathrm{C} 3 \mathrm{AN}$.

The progressive increase of benthic $\delta^{18} \mathrm{O}$ values during the Gauss (180-168.72 mbsf) culminated at the Gauss/ Matuyama boundary (2.47 Ma). During the Gauss, benthic $\delta^{18} \mathrm{O}$ values commonly exceeded Holocene values, but never

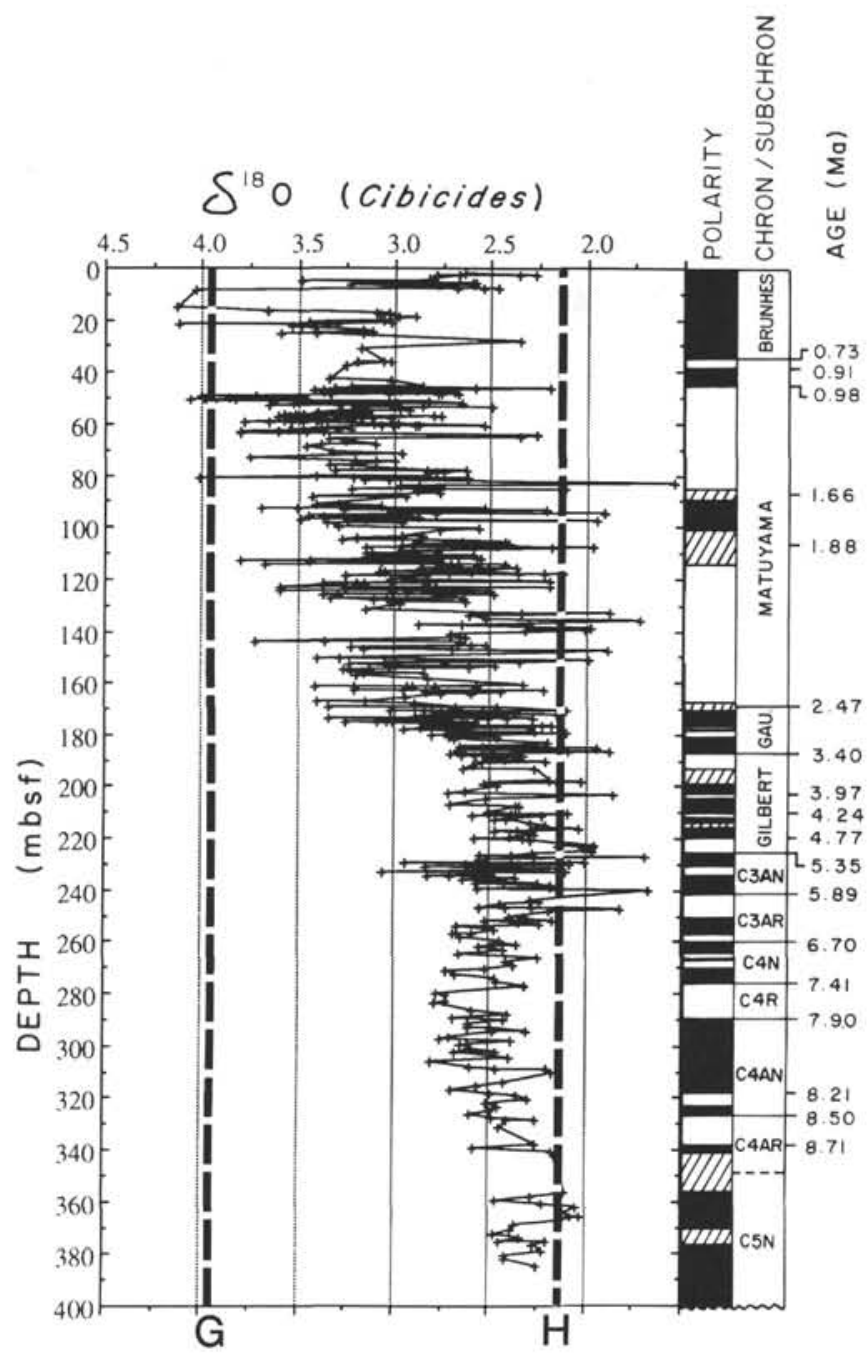

Figure 2. Oxygen isotopic results (per mil relative to PDB) of mixed species of benthic foraminifers belonging to the genera Cibicides and Planulina from Site 704. Sources of isotopic and magnetostratigraphic data are the same as for Figure 1. Note the progressive increase in benthic $\delta^{18} \mathrm{O}$ values during the Gauss Chron. For comparison, the expected $\delta^{18} \mathrm{O}$ values for Cibicides for the last glacial (G) and Holocene $(\mathrm{H})$ periods are shown.

reached values comparable to the last glacial maximum $\left(4.1 \% 0-4.2 \%\right.$ oo). The amplitude of the $\delta^{18} \mathrm{O}$ signal progressively increased upsection during the Pleistocene, and $\delta^{18} \mathrm{O}$ values first reached $4 \%$ at 88 mbsf (1.5-1.6 Ma).

The oxygen isotopic data of fine-fraction carbonate bears little resemblance to either the planktonic or benthic $\delta^{18} \mathrm{O}$ records (Fig. 3). A complete description of the record is given in Mead et al. (this volume). One interesting feature of the record is the high amplitude of the signal above $40 \mathrm{mbsf}$ $(<0.93 \mathrm{Ma})$, where the variation is as great as $4.5 \%$.

\section{Carbon Isotopes}

The carbon isotopic record of $N$. pachyderma is illustrated in Figure 4. Typical glacial and Holocene $\delta^{13} \mathrm{C}$ values from a nearby piston core are provided for comparison. The average amplitude of the $\delta^{13} \mathrm{C}$ signal for the last climatic cycle was $0.8 \%$ in the Southern Ocean (Charles and Fairbanks, 1990).

Carbon isotopic values of $N$. pachyderma averaged $\sim 1.5 \%$ during much of the late Miocene, between 9.7 and 


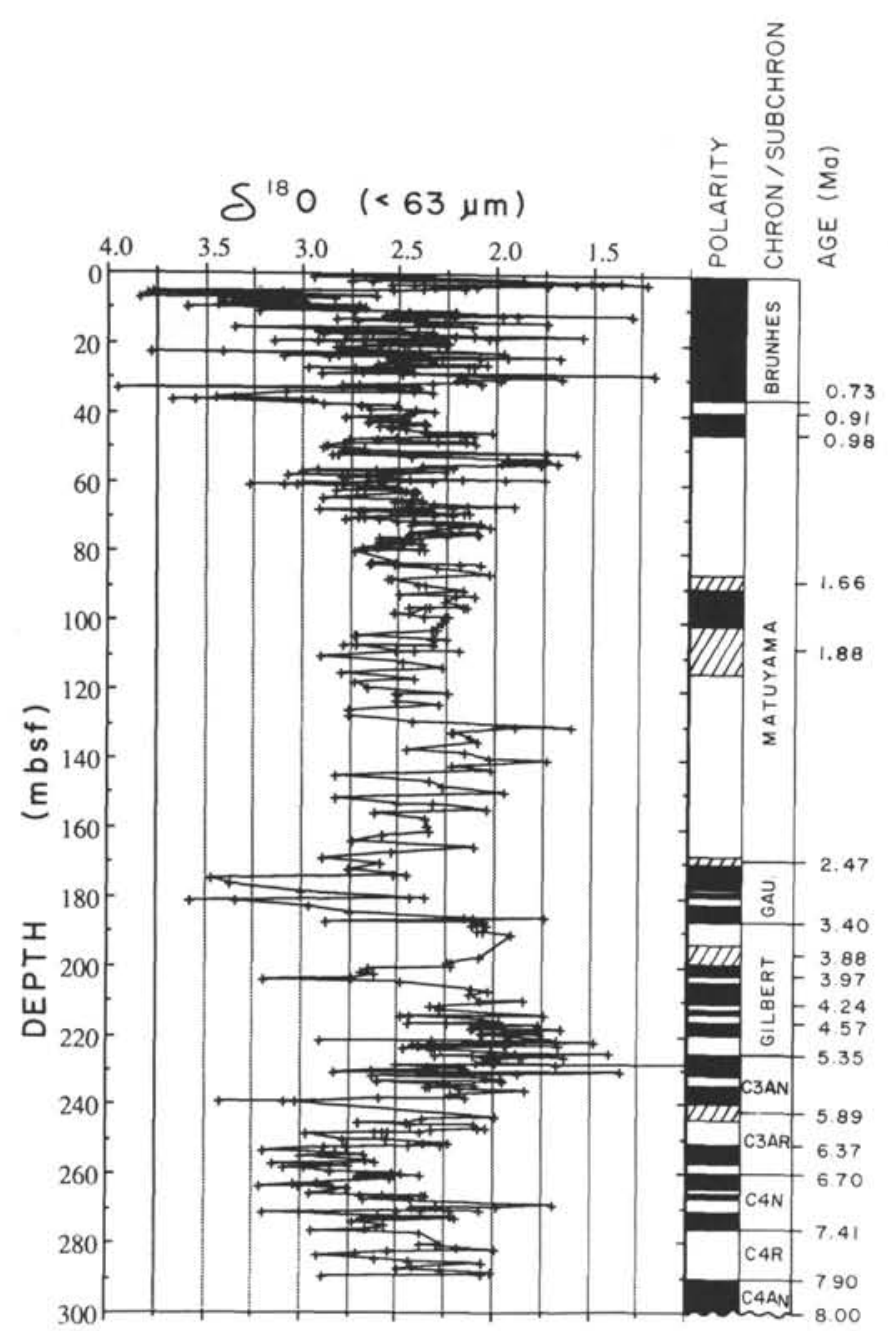

Figure 3. Oxygen isotopic results (per mil relative to PDB) of fine-fraction $(<63 \mu \mathrm{m})$ carbonate from Site 704. Isotopic data are from Mead et al. (this volume) and the magnetostratigraphy is after Hailwood and Clement (this volume).

$\sim 6.4 \mathrm{Ma}$ ( $\sim 380-255$ mbsf; Fig. 4). These values are about $0.5 \%$ heavier than Holocene $\delta^{13} \mathrm{C}$ values at this location. Between $\sim 6.4$ and $6.0 \mathrm{Ma}(255-245 \mathrm{mbsf}), \delta^{13} \mathrm{C}$ values decreased by $1 \%$ and averaged $0.4 \%$ during the remainder of Hole 704B. Although some trends are evident in the upper $250 \mathrm{~m}$, the amplitude of the planktonic $\delta^{13} \mathrm{C}$ signal was fairly constant and averaged $1 \%$ after $6.4 \mathrm{Ma}$ (Fig. 4). This amplitude is roughly comparable to the variability observed between the Holocene and last glacial maximum.

Similar to the planktonic record, benthic $\delta^{13} \mathrm{C}$ values also averaged $\sim 1.5 \%$ oo between 9.7 and $6.4 \mathrm{Ma}$ (380-255 mbsf; Fig. 5). These values are $\sim 1.25 \%$ more positive than typical Holocene values at this site. From $\sim 6.4$ to $6.0 \mathrm{Ma}$ (255-245 mbsf), benthic $\delta^{13} \mathrm{C}$ values decreased by $1 \%$ and averaged $\sim 0.5 \%$. The amplitude of $\delta^{13} \mathrm{C}$ variation between 6.0 and $2.47 \mathrm{Ma}$ was approximately $1 \%$ oo and varied about the estimated Holocene value.

Beginning at $2.5-2.4 \mathrm{Ma}(168.72 \mathrm{mbsf})$, benthic $\delta^{13} \mathrm{C}$ values decreased and averaged $0.0 \%$ during the early Matuyama. The amplitude of the benthic $\delta^{13} \mathrm{C}$ signal progressively increased, reaching a maximum range of $1.5 \%$ during the late Matuyama. This amplitude is slightly greater than that observed for Cibicides in the Southern Ocean between the

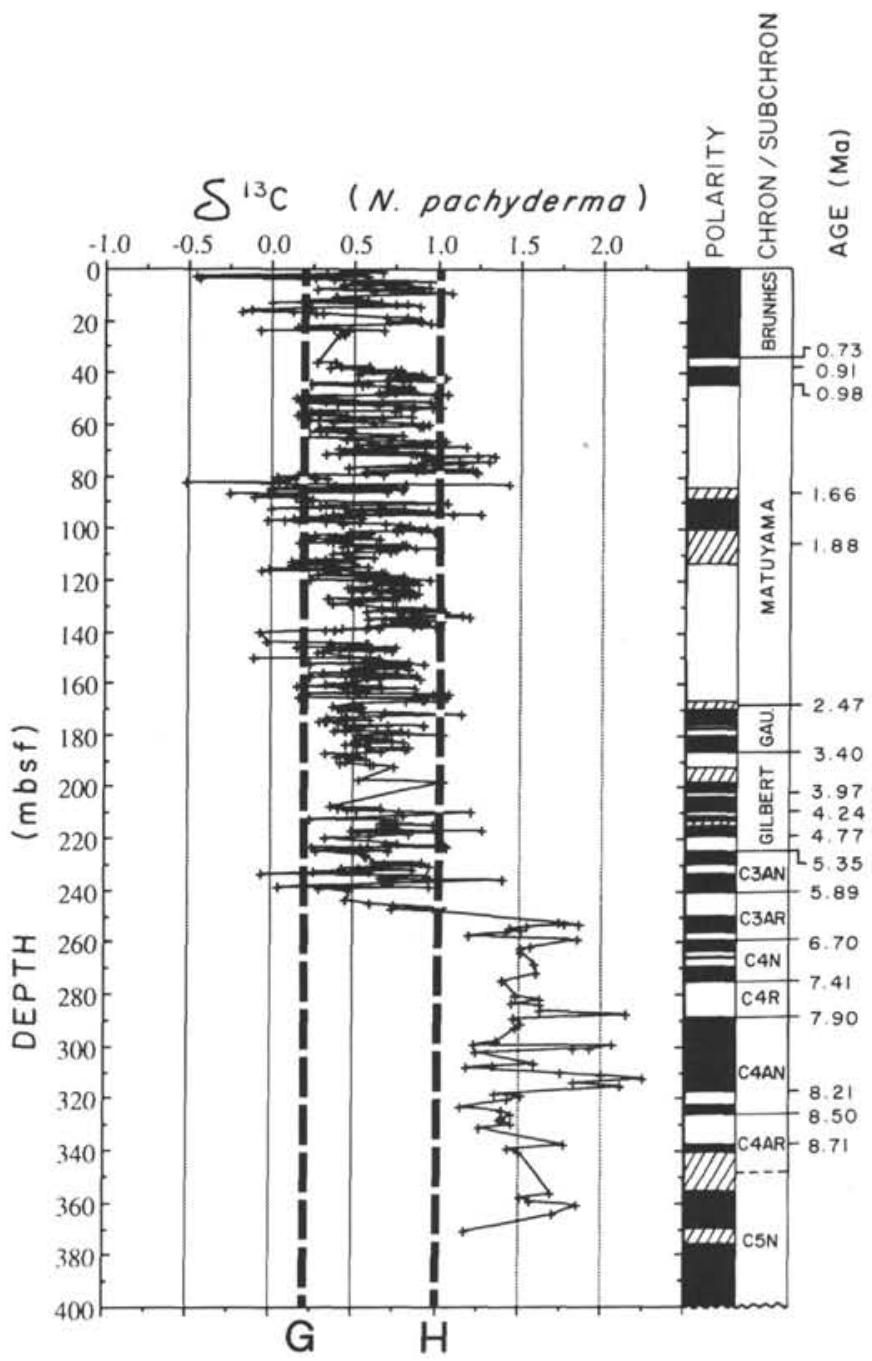

Figure 4. Carbon isotopic results (per mil relative to PDB) of the planktonic foraminifer Neogloboquadrina pachyderma (sinistral) from Site 704. Sources of isotopic and magnetostratigraphic data are the same as for Figure 1. The decrease in $\delta^{13} \mathrm{C}$ values between 255 and 245 mbsf (6.4-6.0 Ma) corresponds to the late Miocene Chron C3AR (Epoch 6) carbon shift. For comparison, typical glacial $(G)$ and Holocene $(\mathrm{H}) \delta^{13} \mathrm{C}$ values are designated for this latitude (Charles and Fairbanks, 1990).

Holocene and last glacial maximum (Charles and Fairbanks, 1990).

Major trends in the $\delta^{13} \mathrm{C}$ of fine-fraction carbonate are roughly similar to the benthic $\delta^{13} \mathrm{C}$ record during the late Neogene, but lead and lag relationships exist (Fig. 6). Between 7.9 and $6.4 \mathrm{Ma}$ (290-255 mbsf), carbon isotopic values were fairly constant and averaged $2 \%$ oo. Beginning at $6.4 \mathrm{Ma}$ (255 mbsf), fine-fraction $\delta^{13} \mathrm{C}$ values began to decrease with the exception of two anomalously positive points near 240 mbsf. This trend of decreasing $\delta^{13} \mathrm{C}$ values continued until 4.2 $\mathrm{Ma}$ (210 mbsf). This decrease is roughly coincident with the late Miocene carbon shift, as observed in the foraminiferal isotopic records, except that the shift in the fine fraction occurred over a period of $2 \mathrm{~m}$.y. rather than a few hundred thousand years. Between $\sim 2.7$ and $2.5 \mathrm{Ma}$ (170-169 mbsf), fine-fraction $\delta^{13} \mathrm{C}$ values abruptly decreased by $\sim 1.5 \%$. This fine-fraction $\delta^{13} \mathrm{C}$ shift slightly precedes the decrease in benthic $\delta^{13} \mathrm{C}$ that occurred at $2.5 \mathrm{Ma}$ (Fig. 5). Above the 


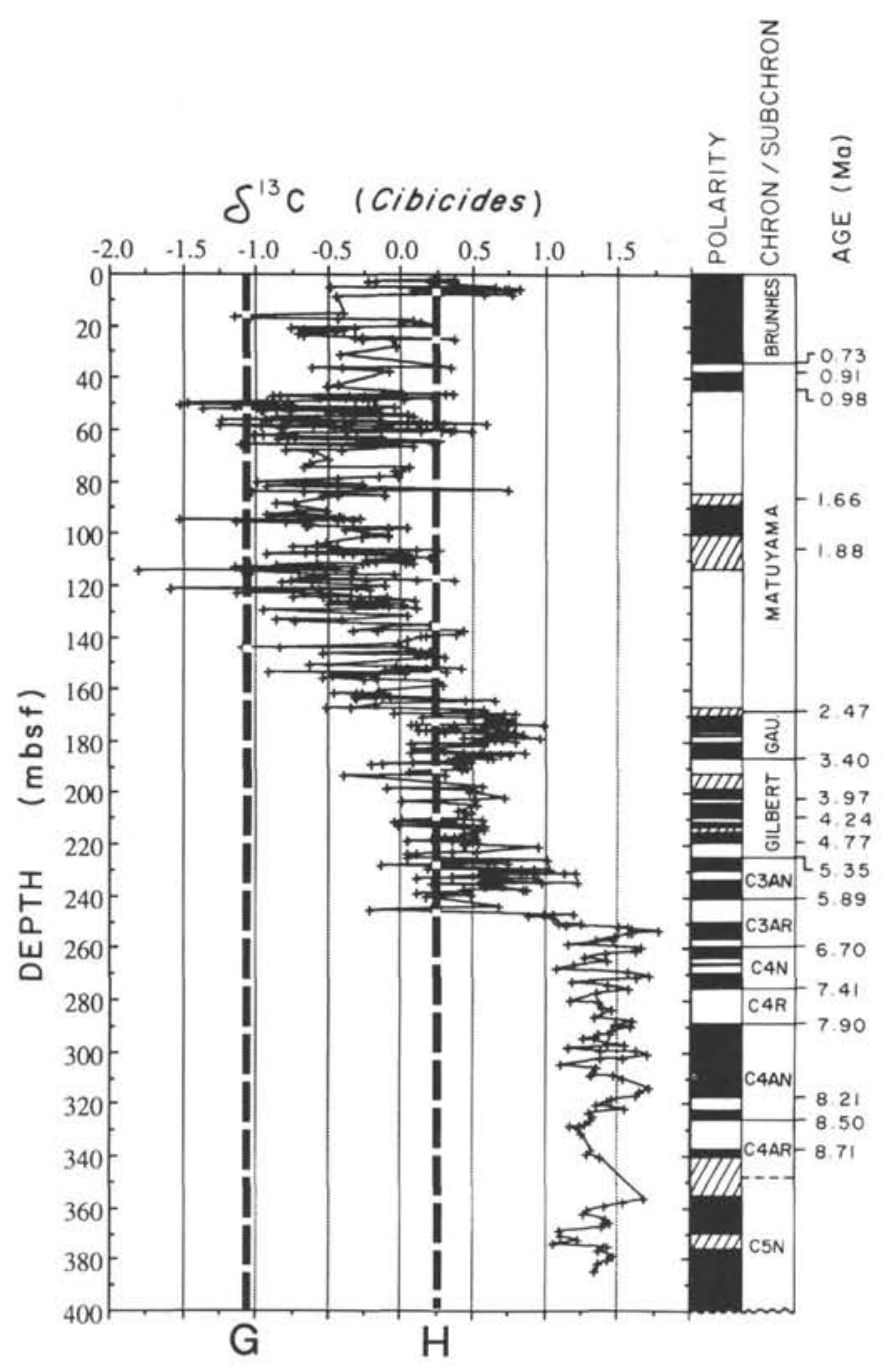

Figure 5. Carbon isotopic results (per mil relative to PDB) of mixed species of benthic foraminifers belonging to the genera Cibicides and Planulina from Site 704. Sources of isotopic and magnetostratigraphic data are the same as for Figure 1. Note the two-step decrease in benthic $\delta^{13} \mathrm{C}$ values between 255 and $245 \mathrm{mbsf}(6.4-6.0 \mathrm{Ma})$ and at the Gauss/Matuyama boundary (169 mbsf; $2.47 \mathrm{Ma}$ ). For comparison, $\delta^{13} \mathrm{C}$ values are provided for the Holocene $(\mathrm{H})$ and last glacial maximum (G) from a nearby core in the subantarctic South Atlantic (Charles and Fairbanks, 1990).

Gauss/Matuyama boundary, fine-fraction $\delta^{13} \mathrm{C}$ values averaged $-0.5 \%$ and the amplitude of the signal was relatively low until $\sim 1.4 \mathrm{Ma}$ (75 mbsf). Above this level, the amplitude of the $\delta^{13} \mathrm{C}$ signal increased markedly and the variation was as great as $\sim 5 \%$.

\section{DISCUSSION}

The late Neogene isotopic records of Site 704 in the subantarctic Southern Ocean are marked by a series of steps or transitions from one climatic-geochemical state to another. Two important transitions in subantarctic paleoceanographic conditions occurred during the late Miocene ( 6.4-4.8 Ma) and late Pliocene $(\sim 2.5 \mathrm{Ma})$.

The late Miocene event began with the carbon shift at 6.4 Ma (255 mbsf). The $\delta^{13} \mathrm{C}$ values of planktonic and benthic foraminifers show a synchronous decrease of $1 \%$ ootween 6.4 and $6.0 \mathrm{Ma}$ (Figs. 4 and 5), whereas the fine-fraction $\delta^{13} \mathrm{C}$

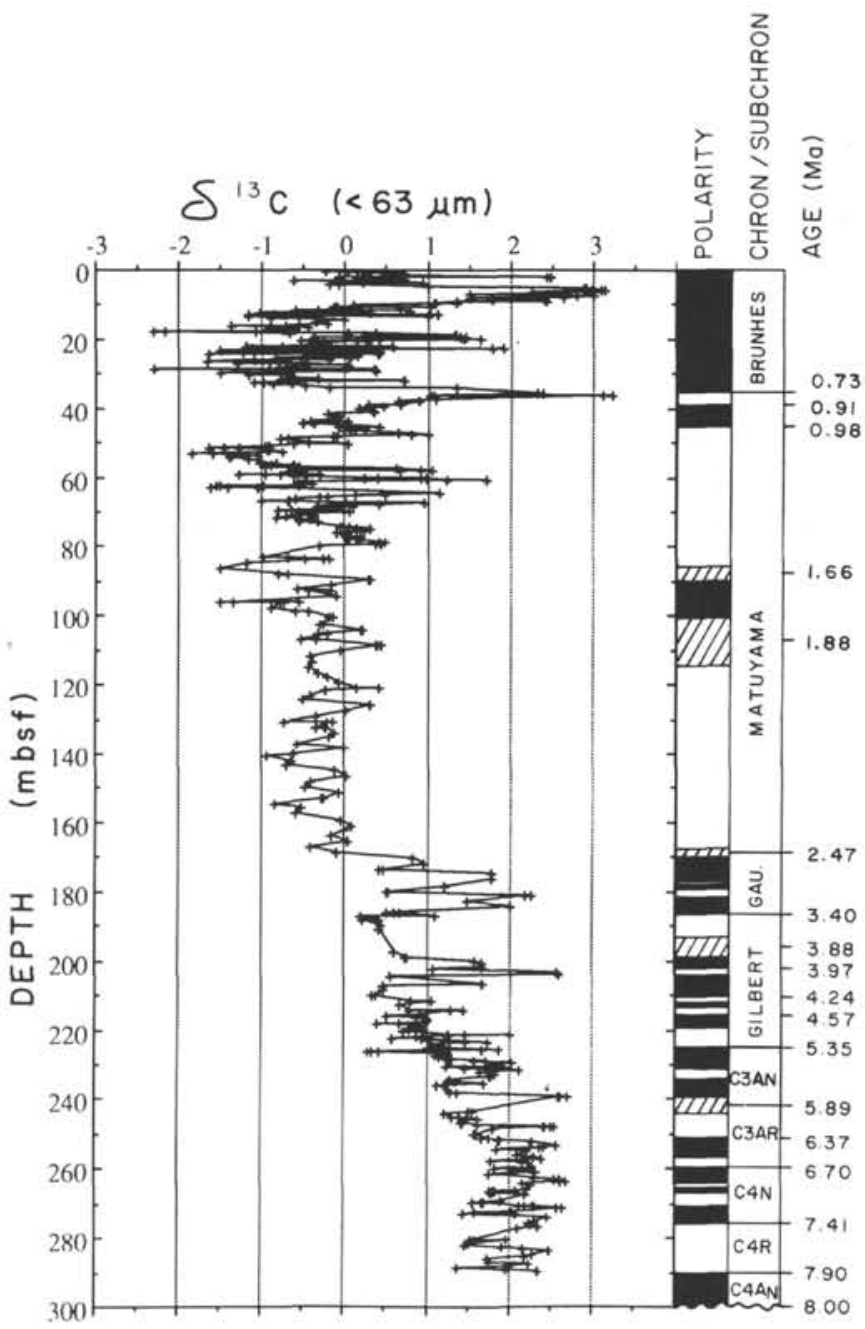

Figure 6. Carbon isotopic results (per mil relative to PDB) of fine-fraction $(<63 \mu \mathrm{m})$ carbonate from Site 704 . Sources of isotopic and magnetostratigraphic data are the same as for Figure 3. Note the two-step decrease in fine-fraction $\delta^{13} \mathrm{C}$ values between 255 and 210 mbsf (6.4-4.2 Ma) and at the Gauss/Matuyama boundary (169 mbsf; $2.47 \mathrm{Ma}$ ). Also note the high-amplitude fluctuations in the upper $40 \mathrm{~m}$ at Site 704 .

record decreases gradually between 6.4 and 4.2 Ma (Fig. 6). The carbon shift during Chron C3AR, observed in surface and deep waters at numerous sites in all ocean basins, signals a global decrease in the mean ${ }^{13} \mathrm{C}$ content of total dissolved $\mathrm{CO}_{2}$ in the oceans. This global event must partly reflect a change in the proportion of carbon stored as organic carbon as opposed to carbonate carbon in sediments, such that organic carbon burial rates decreased relative to carbonate accumulation (Berger and Vincent, 1986).

A new observation from Site 704 is that the beginning of the carbon shift coincides with a time of decreasing benthic $\delta^{18} \mathrm{O}$ values, suggesting warming or decreased global ice volume (Müller et al., this volume). This isotopic evidence is contrary to previous suggestions that the carbon shift was associated with a glacio-eustatic regression that increased erosion rates of organic-rich sediments from the continental shelves. If true, then the initial mechanism of decreased organic carbon burial must be related to tectonic uplift of the continents or changes in storage of organic carbon in deep-sea sediments (for a more complete discussion see Müller et al., this volume). This 
hypothesis requires further testing, as many marginal marine sequences and oxygen isotopic records indicate a regressive phase during the latest Miocene (Adams et al., 1977; Hoddell and Kennett, 1986), although the timing is not well constrained.

The beginning of the carbon shift at $6.4 \mathrm{Ma}$ coincided with a decrease in carbonate content of sediments at Site 704 (Froelich et al., this volume). The interval from 6.4 to $4.8 \mathrm{Ma}$ was marked by relatively low mean carbonate percentages characterized by high-frequency, high-amplitude fluctuations. The low carbonate values, poor preservation of foraminifers, and dominance of terrigenous components suggest that carbonate dissolution was intense during the latest Miocene even at the relatively shallow water depths of Site 704 (2532 m; Froelich et al., this volume). These high-frequency fluctuations in carbonate content indicate rapid oscillations in the position of the lysocline and general instability in the carbonate saturation of deep waters in the Southern Ocean.

Increased carbonate dissolution and an inferred rise in the depth of the carbonate lysocline during the latest Miocene have been reported from many sites (Thunell et al., 1987). At Site 704, the carbonate dissolution event between 6.4 and 4.8 $\mathrm{Ma}$ is temporally equivalent to recent estimates of the duration of the Messinian Stage in the Mediterranean (Channell et al., 1988, 1990; Hilgen and Langereis, 1988), suggesting a potential causal link. The Messinian salinity crisis may have influenced the carbonate saturation of the oceans by diminishing the production rate of NADW and/or by altering temporarily the alkalinity balance of the world's oceans (Ryan et al., 1974; Thunell et al., 1987).

The latest Miocene interval (6.37-4.8 Ma) at Site 704 was marked by anomalously high-amplitude planktonic $\delta^{18} \mathrm{O}$ variations, reflecting rapid temperature and/or salinity changes in subantarctic surface waters. Anomalously low planktonic $\delta^{18} \mathrm{O}$ values $(<1 \%$ o may represent brief deglacial events when large volumes of glacial meltwater were injected into the Southern Ocean. McKenzie and Oberhänsli (1985) first suggested the occurrence of large volumes of isotopically depleted meltwater into the South Atlantic based on planktonic oxygen isotopic data from Deep Sea Drilling Project (DSDP) Site 519. Episodic formation of a deglacial meltwater lid over the source areas for bottom water formation may have halted temporarily the production of Antarctic Bottom Water (AABW) and led to decreased ventilation of the deep basins of the South Atlantic. This mechanism would explain the occurrence of suboxic, laminated organic-carbon-rich sediments found at depths $>4200$ $\mathrm{m}$ in the South Atlantic, such as the diatomaceous Neobrunia ooze in Hole 701 and the Ethmodiscus ooze at DSDP Site 520 . Because the anomalously low $\delta^{18} \mathrm{O}$ values are represented by only a few points, additional measurements are needed to test this hypothesis.

Increased glaciation of Antarctica is indicated for the late Miocene interval, especially during Chron C3AN (Fig. 2). During the late Miocene, average benthic $\delta^{18} \mathrm{O}$ values were nearly equal to Holocene values (Fig. 2), whereas planktonic $\delta^{18} \mathrm{O}$ values of Neogloboquadrina pachyderma were generally less than Holocene values. This may simply reflect that the PFZ was south of its present-day position during much of the late Miocene. During much of Chrons 4 (8.5-6.7 Ma) and $\mathrm{C} 3 \mathrm{AN}(5.89-5.35 \mathrm{Ma})$, benthic $\delta^{18} \mathrm{O}$ values suggest that the ice volume was equal to or slightly greater than that of the Holocene.

Berger (1982) suggested that systems in the state of transition oscillate and are characterized by instability. The latest Miocene event between 6.4 and $4.8 \mathrm{Ma}$ may represent a case in point. High-amplitude, high-frequency fluctuations oc- curred in the temperature and/or salinity of subantarctic surface waters, carbonate saturation of intermediate waters, and ventilation of deep and intermediate water masses. At 4.8 $\mathrm{Ma}$ (base of the Thvera Subchron), the interval of high variability abruptly ended as carbonate content increased in Hole 704A. This event coincided with the restoration of open-marine conditions in the Mediterranean and the termination of evaporite deposition (Channell et al., 1988; Hilgen and Langereis, 1988).

Following the late Miocene event, oxygen isotopes of planktonic foraminifers show two important increases in mean $\delta^{18} \mathrm{O}$ values (Fig. 1). These events are interpreted as coolings of subantarctic surface waters as the Polar Front migrated progressively north. The first increase of $0.5 \%$ occurred between 4.1 and 3.7 Ma during the middle Gilbert Chron, and the second increase occurred at the Gauss/Matuyama boundary (Fig. 1).

The late Pliocene represented a major transition in climate of the subantarctic South Atlantic. Benthic $\delta^{18} \mathrm{O}$ values show a progressive increase during the Gauss (3.4-2.47 Ma), culminating in values that exceed $3.5 \%$ just above the Gauss/ Matuyama boundary $(2.47 \mathrm{Ma})$. Benthic $\delta^{18} \mathrm{O}$ values commonly exceed Holocene core-top values during the Gauss (Fig. 2), suggesting cooler temperatures or a greater ice volume than today.

The Gauss/Matuyama boundary (2.47 Ma) marks an abrupt change in many parameters in Hole 704A: (1) planktonic $\delta^{18} \mathrm{O}$ values increased by $0.5 \%$ oo (Fig. 1), (2) average benthic $\delta^{18} \mathrm{O}$ values increased by $0.25 \%$ and the amplitude of the signal increased after $2.5 \mathrm{Ma}$ (Fig. 2), (3) accumulation rates of biogenic sedimentary components increased by an order of magnitude (Froelich et al., this volume), (4) the accumulation rate of ice-rafted debris increased severalfold (Warnke and Allen, this volume), and (5) carbon isotopic ratios of benthic foraminifers decreased by $\sim 0.5 \%$ (Fig. 5), as did the $\delta^{13} \mathrm{C}$ of fine-fraction carbonate by $1.5 \%$ (Fig. 6), but no change occurred in planktonic $\delta^{13} \mathrm{C}$ values (Fig. 4).

Most of these changes occurred very abruptly at 168.72 mbsf, coinciding with the Gauss/Matuyama boundary (2.47 $\mathrm{Ma}$ ) at the coring break between Cores 114-704A-18X and 114-704A-19X. These data are consistent with the interpretation that the PFZ migrated north at this time, bringing cold, subantarctic waters to $47^{\circ} \mathrm{S}$. Upwelling increased and stimulated both carbonate and siliceous productivity, which resulted in high sedimentation rates at Site 704 during the early Matuyama.

The fact that a decrease in $\delta^{13} \mathrm{C}$ values is observed in benthic foraminifers and fine-fraction carbonate (mostly coccoliths) but not in planktonic foraminifers is problematic. Mead et al. (this volume) suggested that $N$. pachyderma lives deeper in the water column than coccolith species and is precipitating its calcite under near-isothermal conditions below the thermocline. In this case, fine-fraction $\delta^{13} \mathrm{C}$ is controlled by the relative balance between productivity and upwelling, whereas $N$. pachyderma is recording the average $\delta^{13} \mathrm{C}$ of the water being upwelled, and may not be affected by the rate of upwelling.

The decrease in benthic $\delta^{13} \mathrm{C}$ values at $2.5 \mathrm{Ma}$ (Fig. 5) suggests that the ventilation rate of Southern Ocean deep waters decreased and the nutrient content increased at 2.5 Ma. At this time, $\delta^{13} \mathrm{C}$ values at Site 704 shifted away from North Atlantic values and overlapped those of the Pacific (Hodell and Ciesielski, this volume). This shift in $\delta^{13} \mathrm{C}$ of the Southern Ocean toward the Pacific end member represented a decrease in the mixing ratio of NADW and CPDW, probably due to reduced rates of NADW production during glacial events of the early Matuyama. 
The co-occurrence of increased accumulation rates of ice-rafted detritus and increased benthic and planktonic $\delta^{18} \mathrm{O}$ values at the Gauss/Matuyama boundary in Hole $704 \mathrm{~A}$ strongly suggests that a fraction of the ice volume increase at 2.5 Ma occurred on Antarctica. The intensification of glaciation during the late Pliocene was not limited to the Northern Hemisphere, but the volume of ice-sheet expansion in each hemisphere remains uncertain. The relative timing of events between the Southern Ocean and North Atlantic is important for understanding the relationship of climate change between the polar oceans. The onset and intensification of Northern Hemisphere glaciation, as recorded in the North Atlantic, was a gradual process during the late Pliocene that began with brief $\delta^{18} \mathrm{O}$ increases at $3.2,3.1,2.7$, and $2.6 \mathrm{Ma}$ (Keigwin, 1986) and culminated in a $30 \%$ increase in signal amplitude at $2.4 \mathrm{Ma}$ (Raymo et al., 1989). At $2.4 \mathrm{Ma}$, glaciation increased to the point where ice-rafted debris was delivered to the open North Atlantic (Shackleton et al., 1984; Raymo et al., 1989).

The interpreted scenario of climatic changes from the Southern Ocean is similar to that inferred from the North Atlantic. Benthic $\delta^{18} \mathrm{O}$ values progressively increased during the Gauss, culminating with an increase in planktonic and benthic $\delta^{18} \mathrm{O}$ values and the accumulation of ice-rafted detritus at the Gauss/Matuyama boundary. Further refinement of the exact timing of events at Site 704 is needed to determine if lead or lag relationships existed between the isotopic and sedimentologic records of the Southern Ocean and Northern Hemisphere during the late Pliocene.

\section{CONCLUSIONS}

During the latest Miocene (6.4 to $4.8 \mathrm{Ma})$, the Southern Ocean was marked by a major change in the marine carbon cycle, rapid fluctuations in the temperature and/or salinity of subantarctic surface water, and high-amplitude variations in carbonate saturation and ventilation of deep waters. Benthic and planktonic foraminiferal $\delta^{13} \mathrm{C}$ values in Hole 704B show a synchronous decrease of $1 \%$ between 6.4 and $6.0 \mathrm{Ma}$, corresponding to the late Miocene "carbon shift." The amplitudes of the oxygen isotopic and percent carbonate signals are high between 6.4 and $4.8 \mathrm{Ma}$, suggesting markedly fluctuating conditions in subantarctic surface and deep waters. Variations in temperature and salinity may have resulted from instability in the West Antarctic Ice Sheet that introduced episodically large volumes of meltwater to the South Atlantic and temporarily halted the production of AABW. Brief periods of reduced ventilation of the deep basins of the South Atlantic are evidenced by the deposition of suboxic, laminated diatom oozes such as the Neobrunia ooze at Site 704 and the Ethmodiscus ooze at Site 520. The interval of intense carbonate dissolution that occurred in Hole 704B from 6.4 to $4.8 \mathrm{Ma}$ coincided with the Messinian Stage in the Mediterranean, suggesting potential feedback mechanisms between carbonate saturation and the Messinian salinity crisis.

The late Pliocene event $(\sim 2.5 \mathrm{Ma})$ in Hole $704 \mathrm{~A}$ included an increase in global ice volume, a northward migration of the PFZ, and a decrease in the ventilation rate of Southern Ocean deep water. The coincidence of increased foraminiferal $\delta^{18} \mathrm{O}$ amplitude and accumulation rate of ice-rafted detritus in Hole 704A strongly suggests that the late Pliocene event was not limited to ice growth in the Northern Hemisphere and that a fraction of the ice volume increase must have occurred on Antarctica. The relative timing of climatic and oceanographic events between the subantarctic South Atlantic and North Atlantic will be critical for determining the interhemispheric response of the polar oceans during this important climatic transition.

\section{ACKNOWLEDGMENTS}

We thank Susan Case-Ciesielski for illustrative assistance. This research was supported by NSF Grant \#OCE-8858012 and U.S. Science Program (USSAC) Grant \#20114 to DAH and NSF Grant \#DPP-8717854 to PFC and DAH.

\section{REFERENCES}

Adams, C. G., Benson, R. H., Kidd, R. B., Ryan, W.B.F., and Wright, R. C., 1977. The Messinian salinity crisis and evidence of late Miocene eustatic changes in the world ocean. Nature, 269:383-386.

Berger, W. H., 1982. Climate steps in ocean history-lessons from the Pleistocene. In Climate in Earth History: Washington (National Academy Press), 43-54.

Berger, W. H., and Vincent, E., 1986. Deep-sea carbonates: reading the carbon-isotope signal. Geol. Rundsch., 75:249-269.

Channell, J.E.T., Rio, D., and Thunell, R. C., 1988. MiocenePliocene boundary magnetostratigraphy at Capo Spartivento, Calabria, Italy. Geology, 16:1096-1099.

Channell, J.E.T., Torii, M., and Hawthorne, T., 1990. Magnetostratigraphy of sediments recovered during ODP Leg 107 (Tyrrhenian Sea). In Kastens, K. A., Mascle, J., et al., Proc. ODP, Sci. Results, 107: College Station, TX (Ocean Drilling Program), 335-346.

Charles, C. D., and Fairbanks, R. G., 1990. Glacial to interglacial changes in the stable isotopic composition of surface and deep waters in the Southern Ocean. In Bleil, U., and Thiede, J. (Eds.), Geologic History of the Polar Oceans: Arctic versus Antarctic: Dordrecht (Kluwer Academic), 519-538.

Hilgen, F. J., and Langereis, C. G., 1988. The age of the MiocenePliocene boundary in the Capo Rossello area (Sicily). Earth Planet. Sci. Lett., 91:214-222.

Hodell, D. A., and Kennett, J. P., 1986. Late Miocene-early Pliocene stratigraphy and paleoceanography of the South Atlantic and southeast Pacific oceans: a synthesis. Paleoceanography, 1:285311.

Keigwin, L. D., Jr., 1986. Pliocene stable isotope record of Deep Sea Drilling Project Site 606: sequential event of ${ }^{18} \mathrm{O}$ enrichment beginning at 3.1 Ma. In Ruddiman, W. F., Kidd, R. B., et al., Init. Repts. DSDP, 94: Washington (U.S. Govt. Printing Office), 911920.

McKenzie, J. A., and Oberhänsli, H., 1985. Paleoceanographic expressions of the Messinian salinity crisis. In Hsü, K. J., and Weissert, H. (Eds.), South Atlantic Paleoceanography: Cambridge (Cambridge Univ. Press), 99-123.

Raymo, M. E., Ruddiman, W. F., Backman, J., Clement, B. M., and Martinson, D. G., 1989. Late Pliocene variation in Northern Hemisphere ice sheets and North Atlantic Deep Water circulation. Paleoceanography, 4(4):413-446.

Ryan, W.B.F., Cita, M. B., Rawson, M. D., et al., 1974. A paleomagnetic assignment of Neogene stage boundaries and the development of isochronous datum planes between the Mediterranean, the Pacific and Indian oceans in order to investigate the response of the world ocean to the Mediterranean salinity crisis. Riv. Ital. Paleontol., 80:631-688.

Shackleton, N. J., Backman, J., Zimmerman, J., Kent, D. V., Hall, M. A., Roberts, D. G., Schnitker, D., and Baldauf, J., 1984. Oxygen isotope calibration of the onset of ice-rafting and history of glaciation in the North Atlantic region. Nature, 307:620-623.

Thunell, R. C., Williams, D. F., and Howell, M., 1987. AtlanticMediterranean water exchange during the late Neogene. Paleoceanography, 2:661-678.

Date of initial receipt: 17 November 1989

Date of acceptance: 4 January 1990

Ms 114B-188 